\title{
Morphological study of skin biopsy specimens: a contribution to the diagnosis of metabolic disorders with involvement of the nervous system
}

\author{
J.J. MAR T I N A N D C. CEUTER I C K \\ From the Born-Bunge Foundation, Universitaire Instelling Antwerpen, Antwerp, Belgium
}

SUMMARY Skin biopsies were performed in 71 patients affected by the following disorders: ceroid-lipofuscinoses (17 cases), mucopolysaccharidoses (13 cases) mucolipidoses (seven cases), lipidoses (18 cases), metabolic diseases to be further classified (seven cases), acid maltase deficiency (nine cases). After a survey of semithin sections, the skin specimens were examined with the electron microscope. In most of the cases, epithelial cells, hair follicles, fibroblasts, eccrine sweat glands, smooth muscle cells, sebaceous glands, vascular cells, and nerve bundles were available. In 62 cases $(87.3 \%$ ), positive diagnostic information was obtained while in seven other cases $(9.9 \%$ ) suggestive features were discovered which could support the final diagnosis. In only two cases $(2.8 \%)$ were the results negative. We conclude that, in association with enzymatic assays in the cultured fibroblasts, a skin biopsy specimen provides a simple opportunity for the combination of both morphological and biochemical diagnosis of storage disorders, precluding major surgical procedures.

Skin biopsies are routinely used in patients and their heterozygous parents to perform enzymatic and morphological studies on established fibroblast strains. Although enzymatic assays are decisive in making the diagnosis of many metabolic disorders, the use of electron microscopy as a further diagnostic tool on cultured skin fibroblasts has given less consistent and sometimes contradictory results (Kamensky et al., 1973; Lyon et al., 1973). The more optimistic conclusions of Wyatt and Cox (1977) are difficult to accept for two reasons: (i) artefacts due to culturing and preparative techniques, as well as the senescence of fibroblasts, tend to obscure the ultrastructural abnormalities related to the genotype of the cells involved if such specific features are really to be observed; (ii) indeed, with very few exceptions, the inclusions present in these cells are not similar to the ones stored in the patients' tissues.

Since this type of electron microscope study can only be made after cell growth and consecutive

This work was supported by the "Fonds voor geneeskundig wetenschappelijk onderzoek" (Grant 3.0033.77) and by the Baron Charles Bracht Foundation.

Address for correspondence and reprint requests: Professor Dr J. J. Martin, Born-Bunge Stichting, Universitaire Instelling Antwerpen, 1 Universiteitsplein, B-2610 Wilrijk (Antwerp), Belgium.

Accepted 2 October 1977 passages in culture, it is easier, faster, and more rewarding to examine skin biopsy specimens in which many different cell types can be found. But for a few case reports on mucopolysaccharidoses and GM 1 gangliosidosis (Scheie et al., 1962; Roels et al., 1970; Vissian et al., 1970), the advantages of this simple technique were demonstrated unequivocally by the comprehensive study of Carpenter et al. (1972) on involvement of skin, muscle, and nerve in ceroid-lipofuscinoses. To conclude our previous papers on that topic (Martin and Jacobs, 1973; Martin and de Groote, 1974; Ceuterick et al., 1976; Martin et al., 1976a, b; Libert et al., 1978) we report on 71 patients affected by various metabolic disorders.

\section{Cases and methods}

The cases are listed in Table 1. The diagnoses result from the following investigations: full clinical examination including fundi, genetic information, relevant complementary studies such as electroencephalography, electromyography, radiology, ophthalmological evaluation, biopsies, and, whenever possible, postmortem reports, and demonstration of the enzymatic deficiency (when known) on cultured fibroblasts and leucocytes. 
Table 1 List of cases with results of skin biopsies

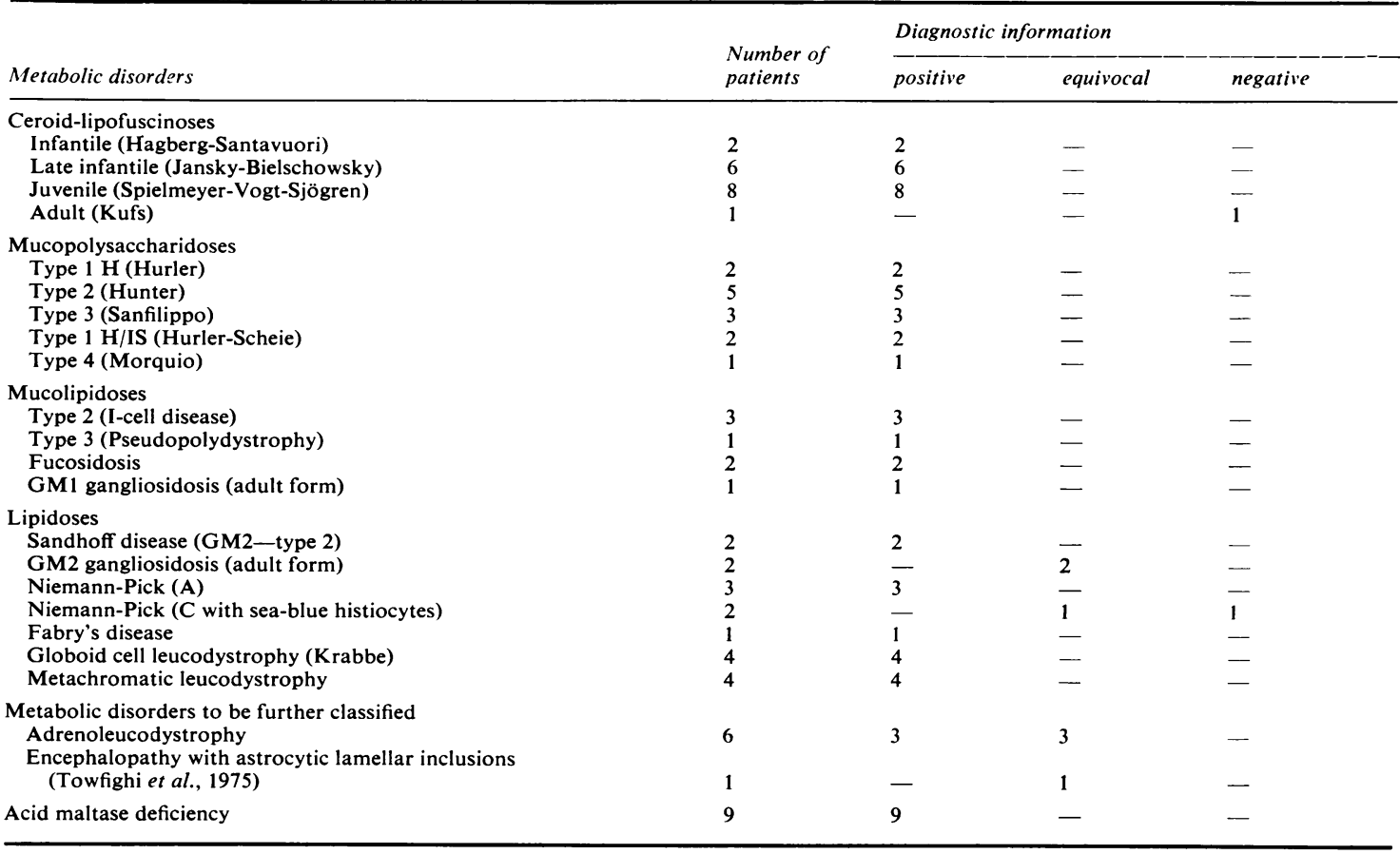

The technique of the skin biopsy has been reported previously (Martin and Jacobs, 1973; Martin and de Groote, 1974).

\section{Results}

Our results are presented in the following tables and figures: Table 2 and Fig. 1 for the ceroidlipofuscinoses, Table 3 and Fig. 2 for the mucopolysaccharidoses, Table 4 and Figs 3 and 4 for the mucolipidoses, Table 5 and Figs 5 and 6 for the lipidoses, Table 6 for metabolic disorders to be further classified, and Table 7 for acid maltase deficiency.

\section{Discussion}

\section{CEROID-LIPOFUSCINOSES}

Our present study fully confirms our previous reports and similar papers on isolated cases (Dolman and Chang, 1972; Carpenter et al., 1973; Rapola and Haltia, 1973; Anzil et al., 1975; ArsénioNunes and Goutières, 1975; de Baecque et al., 1976; Farrell and Sumi, 1977) or on series of cases (Carpenter et al., 1972, 1977; Dolman et al., 1975). Inclusions similar to the ones found in the nervous system and visceral organs of patients respectively affected by the infantile or late infantile ceroid-lipofuscinosis are discovered in nearly all cell types of the skin. We have been able to confirm such resemblances by performing comparative ultrastructural studies on skin biopsy specimens and necropsy tissues of two patients (one with infantile and one with late infantile ceroidlipofuscinosis. The inclusions specific for each disorder are easily detected even at relatively early stages (Ceuterick et al., 1976) or at least at the first full diagnostic investigation.

In juvenile ceroid-lipofuscinosis the pleomorphism of the inclusions found in the nervous system (except for a few reports by van Haelst and Gabreëls, 1972; Carpenter et al., 1973, much less is known on the visceral organs of these older patients) is matched by the variety in the ultrastructural pattern of the inclusions found in the skin and its appendages. Curvilinear profiles can be prevalent as well as rectilinear or "fingerprint" lamellar arrays. Since the inclusions are smaller and less numerous, a thorough search is necessary to find them. Therefore, false negative results (O'Brien et al., 1975) can be expected.

In the ceroid-lipofuscinoses the electron microscope study of the skin of obligate heterozygotes and of cultured fibroblasts from patients is unrewarding.

Our experience concerning the diagnosis of 


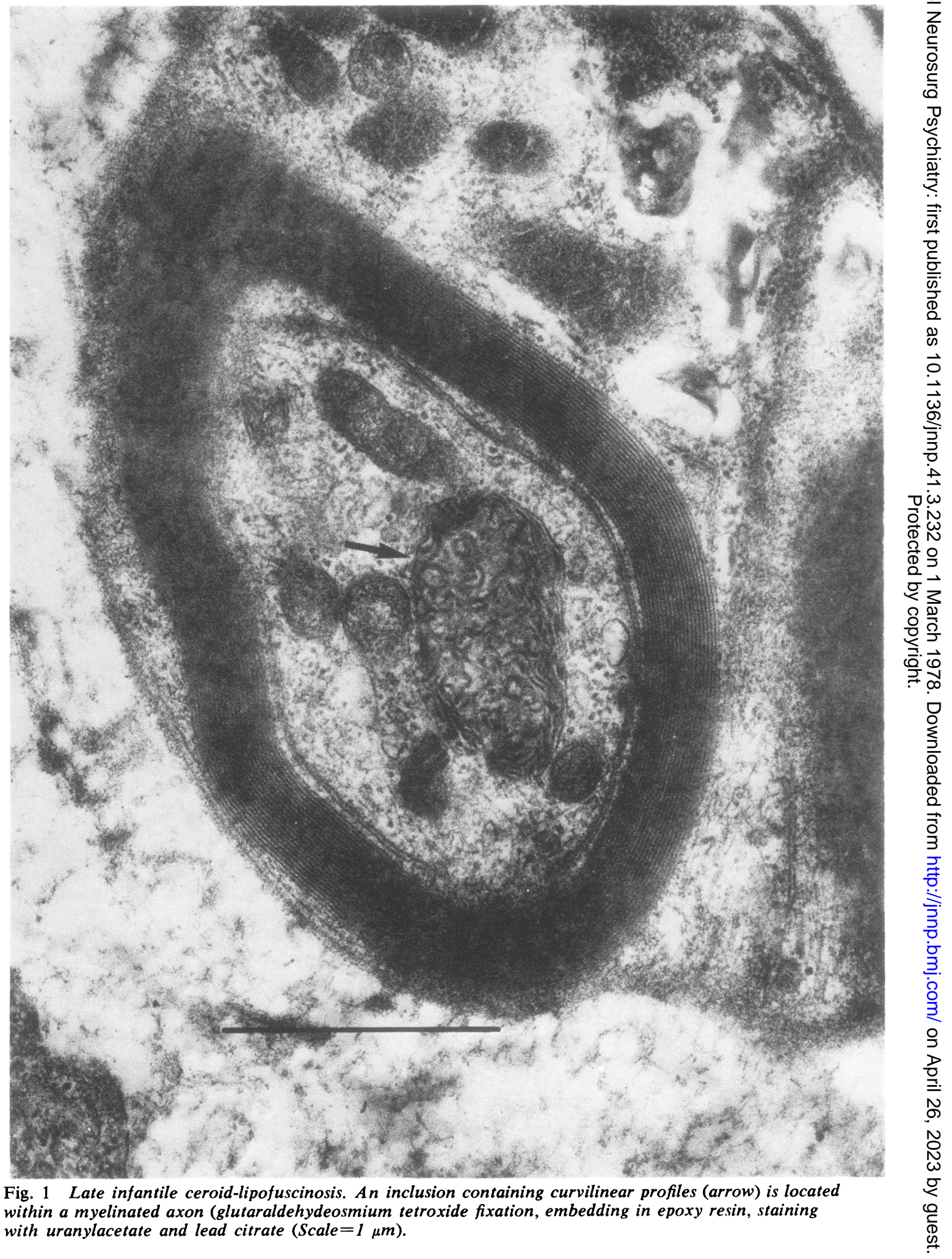


Table 2 Ceroid-lipofuscinoses-morphological findings in skin

\begin{tabular}{ll}
\hline Type & Electron microscopy \\
\hline Infantile & $\begin{array}{l}\text { Inclusions with granular osmiophilic deposits in eccrine sweat glands, Schwann cells, } \\
\text { smooth muscle cells, vascular cells, fibroblasts, hair follicles, and basal epithelial cells. } \\
\text { Inclusions with short lamellar profiles (curvilinear, rectilinear, polygonal, or ring-like) } \\
\text { in endothelial cells. } \\
\text { Late infantile }\end{array}$ \\
$\begin{array}{l}\text { Inclusions with curvilinear profiles in all cell types including Merkel cells, } \\
\text { neurosensory endings, axons, and sebaceous glands. } \\
\text { Cultured fibroblasts from patients and skin of obligate heterozygotes do not contain } \\
\text { such inclusions. } \\
\text { Suvenile }\end{array}$ & $\begin{array}{l}\text { Smaller and less numerous inclusions with curvilinear, rectilinear, and fingerprint } \\
\text { profiles in all cell types with a prevalence for vascular cells. No inclusions found in } \\
\text { skin of obligate heterozygotes. } \\
\text { No lesions in skin and conjunctival biopsy specimens. } \\
\text { In the skeletal muscle, inclusions with poorly formed or disorganised curvilinear } \\
\text { profiles were found. They were similar to the ones found at necropsy in the brain of } \\
\text { an affected brother. }\end{array}$ \\
\hline
\end{tabular}

Kuf's disease by skin biopsy is limited to a 32 year old patient in whom two skin and one conjunctival biopsy have failed to reveal significant features while a biopsy specimen of a skeletal muscle has shown, in the subsarcolemmal areas, inclusions with poorly formed and disorganised curvilinear profiles similar to those discovered at necropsy in the brain of an affected brother.

We do not have reliable enzymatic assays for the ceroid-lipofuscinoses (Pilz et al., 1976). A skin biopsy offers a simple way to diagnose most, if not all, of this group. It is no longer necessary to resort to biopsies of neurone-containing tissues (brain, rectum, vermiform appendix). A parallel study on conjunctival biopsy specimens from 10 patients with ceroid-lipofuscinoses gives similar results (Libert et al., 1978).

\section{MUCOPOLYSACCHARIDOSES}

Vacuolisation of the secretory coils of the eccrine sweat glands and of the fibroblasts is already depictable on semithin sections, the severe distortion of cellular architecture of eccrine glands being especially striking. The electron microscope re- veals the presence of membrane-bound vacuoles which are almost emptied of their contents, leaving only a little fibrillo-granular and lamellar debris as expected when mucopolysaccharides are stored. Only Schwann cells contain lamellar inclusions indicating a storage of complex lipids.

Comparable lesions are found in types 1,2 , and 3 mucopolysaccharidoses, and therefore, except for subtle quantitative changes, it is not possible to rely on morphological features to make a differential diagnosis between these disorders.

In type 4 mucopolysaccharidosis, the vacuoles are less numerous in the fibroblasts. We could not find eccrine glands in the case made available to us.

Finally, we have studied two cases of mucopolysaccharidosis type $1 \mathrm{H}$-IS (Hurler-Scheie compound syndrome). Taking artefactual postmortem changes into account in one case, smaller and lesser vacuoles than in Hurler disease are found.

The value of skin and conjunctival biopsies in the mucopolysaccharidoses was indicated by Scheie et al. (1962) and cursorily mentioned by Neimann et al. (1968). It was demonstrated by Quigley and

Table 3 Mucopolysaccharidoses-morphological findings in skin

\begin{tabular}{|c|c|}
\hline Diseases & Light (LM) and electron (EM) microscopy \\
\hline Type $1 \mathrm{H}$ (Hurler) & $\begin{array}{l}\text { LM : vacuolisation of secretory coils of eccrine sweat glands, bulbs of hair follicles, } \\
\text { fibroblasts. } \\
\text { EM : membrane-bound vacuoles which are either empty or contain small amounts of } \\
\text { fibrillo-granular material and a few lamellar profiles in all cell types but mainly } \\
\text { in fibroblasts and eccrine sweat glands. } \\
\text { Lamellar inclusions in Schwann cells. }\end{array}$ \\
\hline Type 2 (Hunter) & Similar lesions \\
\hline Type 3 (Sanfilippo) & Similar lesions \\
\hline Type 1 H-IS (Hurler-Scheie) & $\begin{array}{l}\text { LM: no overt vacuolisation of eccrine sweat glands; tiny vacuoles in fibroblasts. } \\
\text { EM: smaller and less numerous membrane-bound vacuoles in fibroblasts. }\end{array}$ \\
\hline Type 4 (Morquio) & $\begin{array}{l}\text { LM: no overt vacuolisation of the cells; no eccrine sweat glands found in the } \\
\text { specimens examined. } \\
\text { EM: small membrane-bound vacuoles in fibroblasts, very seldom in Schwann cells. }\end{array}$ \\
\hline
\end{tabular}




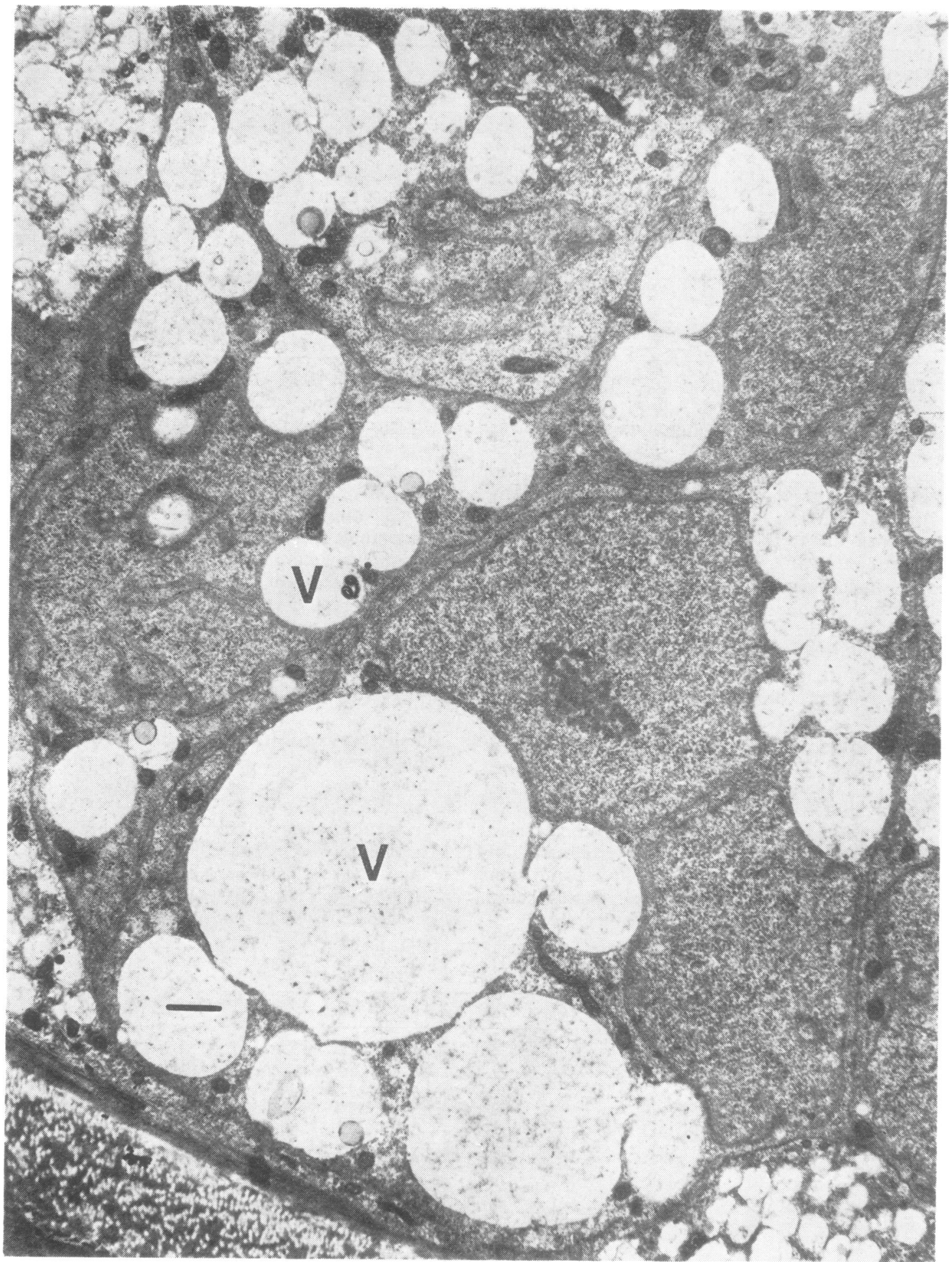

Fig. 2 Mucopolysaccharidosis type 2. Numerous membrane-bound clear vacuoles $(V)$ are present in the cells of the eccrine sweat glands (same techniques as Fig. 1 . Scale $=1 \mu \mathrm{m}$ ). 
Goldberg (1971), Vissian et al. (1971), Kenyon et al. (1972), Belcher (1972, 1973), Quigley and Kenyon (1974), Spicer et al. (1974), Bioulac et al. (1975), Lasser et al. (1975, before and after an ineffectual plasma infusion therapy), O'Brien et al. (1975, 1976a), Kenyon (1976), and Libert (1977) in different types of mucopolysaccharidoses.

\section{MUCOLIPIDOSES}

The term mucolipidosis has been coined by Spranger and Wiedemann (1970) to designate inherited metabolic diseases characterised by the storage of excessive amounts of acid mucopolysaccharides and sphingolipids or glycolipids. It is difficult to apply it to disorders such as I-cell disease or pseudopolydystrophy respectively classified as mucolipidosis types 2 and 3 since no storage of either mucopolysaccharides or lipids could be demonstrated (Martin et al., 1975). However, we shall follow Spranger and Wiedemann's classification.

In type 2 mucolipidosis (I-cell disease), the single most characteristic feature is the accumulation of membrane-bound vacuoles in mesenchymal cells (mainly fibroblasts). This applies to both conjunctival and skin biopsy samples (Kenyon and Sensenbrenner, 1971; Tondeur et al., 1971). Another significant finding consists of the presence of inclusions with small lamellar rings closely or loosely packed together. Such inclusions are found in endothelial cells, in photoreceptors of the retina, in lymphocytes, and perhaps also in the placental syncytiotrophoblastic layer (Rapola et al., 1974;
Aula et al., 1975; Abe et al., 1976; Libert et al., 1977b; Martin and Libert, 1977; Rapola and Aula, 1977). As no similar association has yet been described in other metabolic disorders, it can, for the present at least, be considered as specific for type 2 mucolipidosis. A second interesting point is that these alterations can be found at any age either in fetuses with I-cell disease (Aula et al., 1975; Abe et al., 1976) or immediately after birth. In one of our cases, significant features were discovered at three weeks of age, and found again without any significant differences three months later. A last point concerning type 2 mucolipidosis is the well-known I-cell phenotype in cultured fibroblasts - that is, the filling of the cytoplasm by innumerable pleomorphic electron-dense inclusions (Hanai et al., 1971). However, such inclusions are in no way comparable to the ones found in the affected tissues. Similar granules can be observed, at later stages and in lesser amounts, in aging control cultures (Tenconi et al., 1972; personal data) or under the action of antilysosomal antibodies (Van Hoof, 1972).

In type 3 mucolipidosis, which probably has a similar pathogenesis as type 2 although the two disorders are clinically distinct (Leroy and O'Brien, 1976), the vacuolation in uncultured fibroblasts is less severe as already stressed by Quigley and Goldberg (1971) who also reported the simultaneous presence of membranous lamellar vacuoles. The I-cell phenotype is present in cultured fibroblasts.

In the recently identified type 4 mucolipidosis,

Table 4 Mucolipidoses-morphological findings in skin

\begin{tabular}{|c|c|}
\hline Diseases & Light $(L M)$ and electron $(E M)$ microscopy \\
\hline Type 2 (I-cell disease) & $\begin{array}{l}\text { LM: vacuolated fibroblasts } \\
\text { EM: membrane-bound vacuoles which are empty but for minimal amounts of } \\
\text { reticulogranular material and a few lamellar profiles in fibroblasts and Schwann } \\
\text { cells; inclusions with small rectilinear, polygonal, or ring-like lamellar profiles } \\
\text { in vascular cells. } \\
\text { Numerous electron-dense polymorphic inclusions in cultured fibroblasts. }\end{array}$ \\
\hline Type 3 & $\begin{array}{l}\text { LM: vacuolated fibroblasts } \\
\text { EM: vacuoles with "empty" contents in uncultured fibroblasts, I-cell phenotype in } \\
\text { cultured fibroblasts. }\end{array}$ \\
\hline Fucosidosis & $\begin{array}{l}\text { LM: vacuolisation of eccrine sweat glands (secretory coils and excretory ducts), } \\
\text { endothelial cells, fibroblasts, and Schwann cells. } \\
\text { EM: coexistence of electron-lucent vacuoles with small amounts of granules and } \\
\text { lamellar profiles and of denser vacuoles with a finely granular osmiophilic } \\
\text { material in eccrine sweat glands, vascular cells, fibroblasts, and Schwann cells. } \\
\text { Dense inclusions containing lamellae in Schwann cells. } \\
\text { A few dystrophic amyelinic axons. }\end{array}$ \\
\hline GM1-gangliosidosis (adult variant) & $\begin{array}{l}\text { LM: vacuolisation of endothelial cells, fibroblasts, Schwann cells, and of some basal } \\
\text { epithelial cells. } \\
\text { EM: membrane-bound vacuoles with fibrillogranular contents, a few lamellar profiles, } \\
\text { and denser aggregates in basal epithelial cells, smooth muscle cells, fibroblasts, } \\
\text { and vascular cells. } \\
\text { Inclusions with lipid leaflets and a fibrillogranular reticulum in Schwann cells } \\
\text { around amyelinic axons. } \\
\text { A few dystrophic amyelinic axons. }\end{array}$ \\
\hline
\end{tabular}




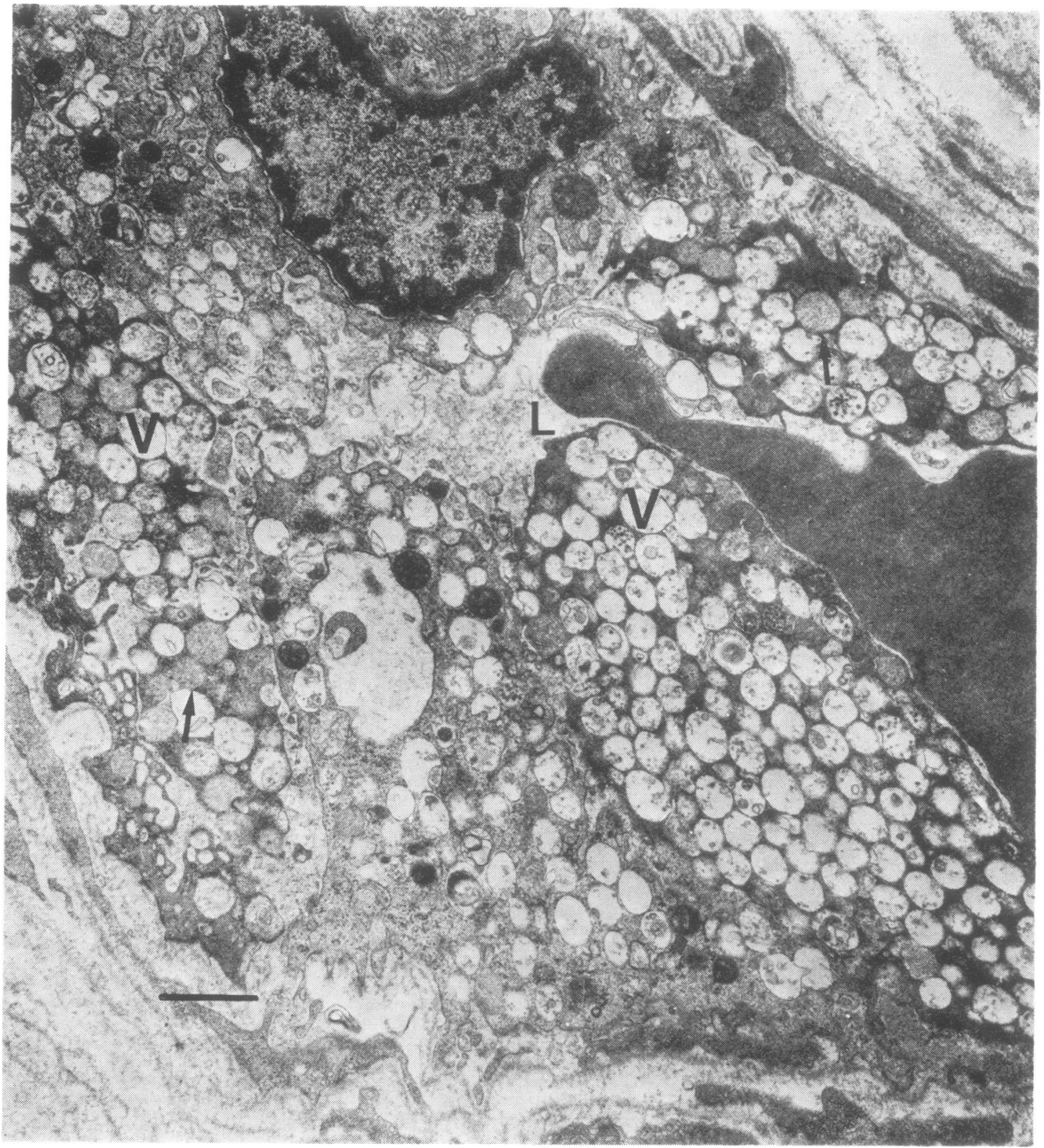

Fig. 3 Fucosidosis. The endothelial cells are full of electron-lucent vacuoles $(V)$; they also contain other vacuoles with a finely granular osmiophilic material (arrows). The lumen $(L)$ of the capillary is narrowed (same techniques as Fig. 1. Scale=1 $\mu \mathrm{m}$ ). 


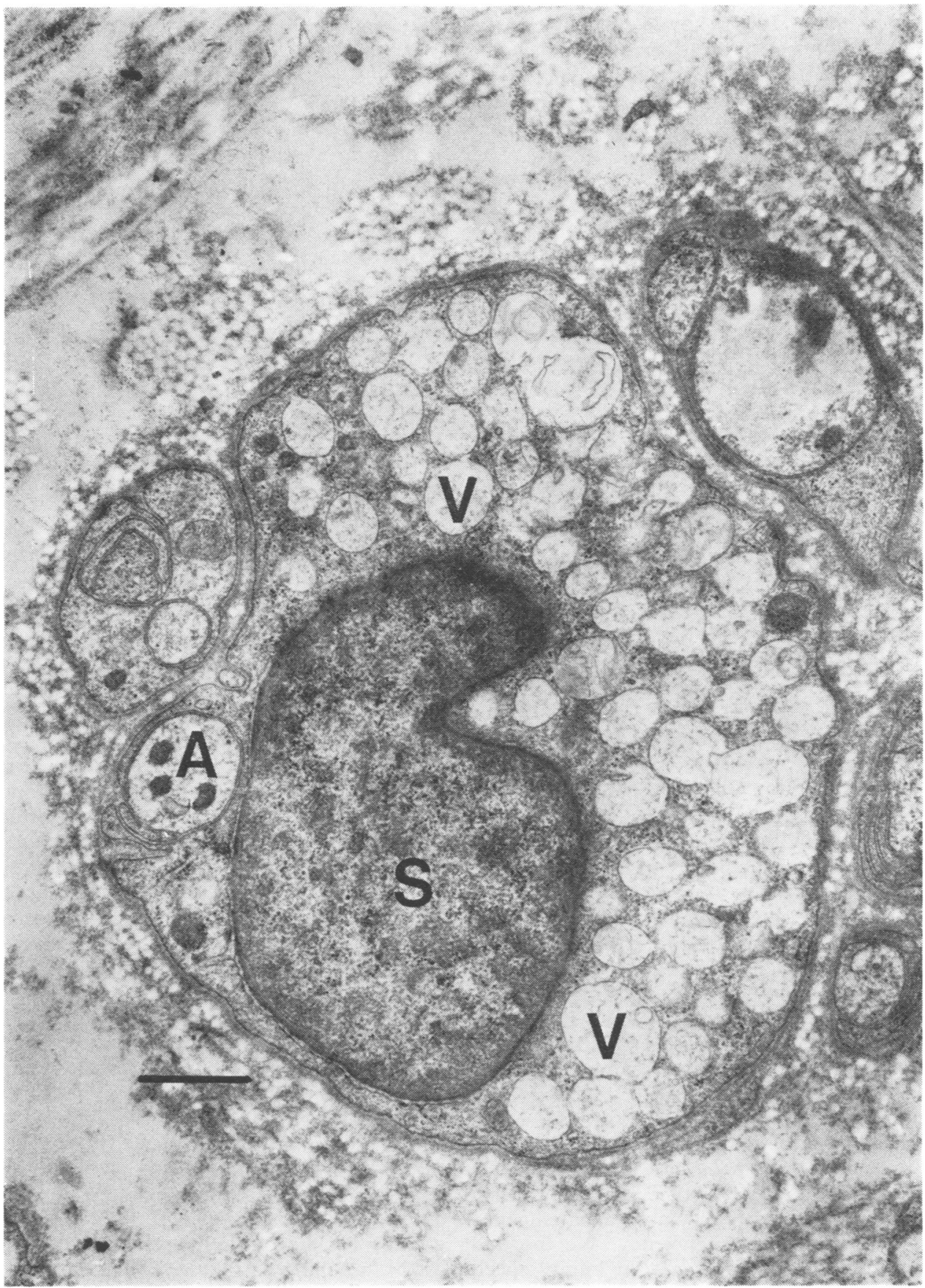

Fig. 4 GM 1 gangliosidosis (adult variant). Numerous "empty" membrane-bound vacuoles $(V)$ fill the cytoplasm of a Schwann cell $(S)$ surrounding amyelinic axons $(A)($ same techniques as Fig. 1. Scale $=1 \mu \mathrm{m}$ ). 
conjunctival biopsy specimens (Merin et al., 1975; Tellez-Nagel et al., 1976) show a combination of vacuoles and of concentric lamellar structures reminiscent of those found in the gangliosidoses but the fundamental biochemical defect has still to be discovered as in the mucolipidoses already discussed.

Fucosidosis, with storage of fucose-containing sphingolipids, oligosaccharides, and polysaccharides also displays interesting features both in conjunctiva and skin. In one of our cases, aged 3 years, with the severe phenotype of the disease, an increased vascular marking was noticeable on the palms of the hands and soles of the feet, accompanied by tortuosity of the retinal blood vessels. No typical angiokeratoma lesions could be discovered as reported in the milder phenotype or in Fabry's disease. As expected, the involvement of the endothelial cells (Patel et al., 1972) was striking. We were able to confirm the vacuolisation of the eccrine sweat glands (Kousseff et al., 1976), and to find lamellar inclusions in Schwann cells (Libert et al., 1977a). Such inclusions have not been reported previously in cutaneous nerve bundles but since many different fucose-containing moieties are stored in fucosidosis, it is not surprising that a variety of inclusions should be found. A more important fact which could represent (Libert et al., 1976b) a pathognomonic finding in fucosidosis is the presence of two types of inclusions, clear ones with heterogeneous contents and denser ones with a finely granular osmiophilic material.

GM 1 gangliosidosis is characterised by the storage of clear vacuoles in mesenchymatous cells and of polymorphic inclusions in Schwann cells. In the most extensively studied type 1, emphasis has been laid on the severe alterations of endothelial cells, the vacuolisation of eccrine sweat glands, and the presence of degenerating or dystrophic axons (Roels et al., 1970; Vissian et al., 1970, 1971; Tommasi et al., 1971; Larbre et al., 1973; Dolman et al., 1975, 1977; O’Brien et al., 1975). Vascular abnormalities of conjunctiva with vacuolation of the endothelial cells have been reported by Boniuk et al. (1976). Much less severe alterations, limited to cutaneous nerves, have been found by O'Brien et al. (1976b) in a 14 year old girl with a unique type of progressive spondylo-epiphyseal dysplasia, normal intelligence and acid $\beta$-galactosidase deficiency. We too had the opportunity to examine a skin biopsy specimen from an adult case of $\beta$-galactosidase deficiency (Loonen et al., 1974; Koster et al., 1976). A most striking clinical feature in this 33 year old Japanese patient was the presence of telangiectasias on sclerae, elbows, thighs, knees, and soles of feet while angiokeratomas were discovered in the umbilical and genital regions. The topography and the fine structure of the stored material in skin and conjunctiva were quite comparable with the findings in type $1 \mathrm{GM} 1$ gangliosidosis.

It is extremely likely that other mucolipidoses will also show ultrastructural alterations in the skin. Positive results are, for example, to be expected in mannosidosis in which conjunctival alterations have already been described (Libert and Tondeur, 1977).

\section{LIPIDOSES}

Our choice of the disorders to be discussed here is, as for the previous categories, dictated by the skin biopsies which were available to us. When considering a given lipidosis, it is easier to discover significant inclusions in the more rapidly fatal variants affecting the youngest patients. The search in adolescents or adults can be more toilsome since the inclusions are smaller, less numerous, and, when present, more difficult to differentiate from lesions due to aging.

In two classical cases of Sandhoff disease, lamellar osmiophilic inclusions, some of them of the membranous cytoplasmic body type, were found in large amounts in different cell types. Many axons contained numerous dense bodies suggesting a disturbed neuronal metabolism. In a case of juvenile Sandhoff disease (MacLeod et al. 1977), the presence of degenerating or dystrophice axons was the only skin alteration. As mentioned? by the same authors, it is true that such intraaxonal deposits are consistent with ganglioside storage disorders but they are certainly not specific. In two adult sisters with spinocerebellar degeneration and low activities of hexosaminidase A and B (Oonk et al., 1978), showing some similarities with the cases reported by Rapin et al. (1976), we found, besides degenerating amyelinic axons, a few intra-axonal and intra-schwannian inclusions with parallel or concentric lamellar profiles. We interpreted our results as supporting the diagnosis of GM 2 gangliosidosis indicated by the enzymatic assays.

In Niemann-Pick disease, clear-cut signs of complex lipid storage have been found in the skin of patients lacking total sphingomyelinase whether they belong to the classical A variant with a rapidly fatal evolution, or to the group of cases with a more prolonged course, confirming previous or simultaneous studies on the same patients (Libert and Danis, 1975; Libert, 1977). In an atypical form of Niemann-Pick disease, with sea-blue histiocytes and normal total sphingomyelinase activity, skin and conjunctival biopsy 
Table 5 Lipidoses-morphological findings in skin

\begin{tabular}{|c|c|}
\hline Diseases & Light ( $L M)$ and electron (EM) microscopy \\
\hline Sandhoff & $\begin{array}{l}\text { LM: tiny granules in the walls of blood vessels. } \\
\text { EM: numerous small osmiophilic inclusions containing lipid-leaflets ("zebra"-like or } \\
\text { "membranous cytoplasmic body"-like) and a granulovesicular material in } \\
\text { fibroblasts, vascular cells, smooth muscle cells, perineurial cells, Schwann cells, } \\
\text { eccrine sweat glands, sebaceous glands. } \\
\text { Dystrophic amyelinic axons. }\end{array}$ \\
\hline GM2 gangliosidosis (adult form) & $\begin{aligned} \text { LM: } & \text { no abnormalities. } \\
\text { EM : } & \text { moderate to minimal amounts of small inclusions containing lipid leaflets in } \\
& \text { amyelinic and myelinic axons, also but very seldom in Schwann cells. } \\
& \text { Dystrophic amyelinic axons. }\end{aligned}$ \\
\hline Niemann-Pick (A) & $\begin{array}{l}\text { LM: granules and vacuoles in distended fibroblasts, vascular cells, eccrine sweat } \\
\text { glands; granules in Schwann cells and endoneurial fibroblasts. } \\
\text { EM: osmiophilic inclusions containing parallel or concentric lipid leaflets in hair } \\
\text { follicles, sebaceous glands, eccrine sweat glands, vascular cells, smooth muscle } \\
\text { cells, fibroblasts, perineurial cells, Schwann cells, and occasionally in axons. } \\
\text { Minimal amounts of myelin breakdown and a few dystrophic amyelinic axons. }\end{array}$ \\
\hline Niemann-Pick (C with sea-blue histiocytes) & $\begin{array}{l}\text { LM: no abnormalities. } \\
\text { EM: equivocal findings in one out of the two cases (a few lamellar osmiophilic } \\
\text { inclusions in fibroblasts). }\end{array}$ \\
\hline Fabry & $\begin{array}{l}\text { LM : granules in fibroblasts, vascular cells, perineurial cells, eccrine sweat glands. } \\
\text { EM: osmiophilic lamellar inclusions in the same cells. }\end{array}$ \\
\hline Krabbe & $\begin{array}{l}\text { LM: no significant abnormalities. } \\
\text { EM: free or intravacuolar spicular inclusions in endoneurial fibroblasts and Schwann } \\
\text { cells around myelinic axons. } \\
\text { Some evidence of demyelination in nerve fascicles. } \\
\text { Skin and cultured fibroblasts from obligate heterozygotes are normal. }\end{array}$ \\
\hline Metachromatic leucodystrophy & $\begin{array}{l}\text { LM: evidence of demyelination. } \\
\text { EM: prismatic and lamellar inclusions in endoneurial fibroblasts, "tuffstone-bodies" } \\
\text { in Schwann cells surrounding myelinic and amyelinic axons. } \\
\text { Demyelination in nerve fascicles. } \\
\text { Skin from obligate heterozygotes is normal. }\end{array}$ \\
\hline
\end{tabular}

samples of two affected siblings failed to demonstrate unequivocal storage features despite the postmortem confirmation of the diagnosis in the $14 \frac{1}{2}$ year old brother.

In Krabbe's disease and in metachromatic leucodystrophy, both characterised by a diffuse involvement of the cerebral white matter and also by a progressive demyelination of the peripheral nerves, it is not surprising that dermal nerve bundles should also contain specific inclusions associated with a moderate to severe demyelination as indeed found in our series of cases.

In Fabry's disease, the presence of angiokeratomas is a strong indication for a biopsy (Hashimoto et al., 1965). The study of any piece of skin will demonstrate the storage of lamellated inclusions in nearly all cell types with a marked predilection for fibroblasts, endothelial cells (the hypertrophy of which can lead to some degree of capillary obstruction) and perineurial cells, usually sparing the Schwann cells. Female carriers can be detected as demonstrated by Libert et al. (1976a) by conjunctival biopsies associated with enzymatic assays of thermolabile $\alpha$-galactosidase in tears; this search for heterozygotes should also be applied to skin biopsies. Finally, it must be mentioned that cultured fibroblasts from patients contain specific lamellated inclusions (Kamensky et al., 1973; McLean and Stewart, 1974; Libert et al., 1976b).

METABOLIC DISORDERS TO BE FURTHER CLASSIFIED Adrenoleucodystrophy is an X-linked neurological disorder characterised by a progressive degeneration of the cerebral white matter associated with adrenal insufficiency. It is a generalised metabolic disorder with evidence of storage in brain, adrenals, testes, and occasionally in peripheral nerves (Schaumburg et al., 1975). We have observed features of storage in dermal and conjunctival nerve fascicles of one patient (Martin et al., 1977b). Our present study on six cases including one adult has confirmed the presence of clear spicular clefts in Schwann cells surrounding myelinated axons; the lesions were very mild and difficult to discover in three cases. It could, then, at best suggest a diagnosis of adrenoleucodystrophy in correlation with the clinical data. Another interesting feature which could support Schaumburg's opinion is the discovery, in one case at least, of vacuolated eccrine sweat glands such as the ones described in various storage disorders.

The case of a 7 year old male patient with a degenerative encephalopathy since birth stands apart. It represents a second example of an ill- 


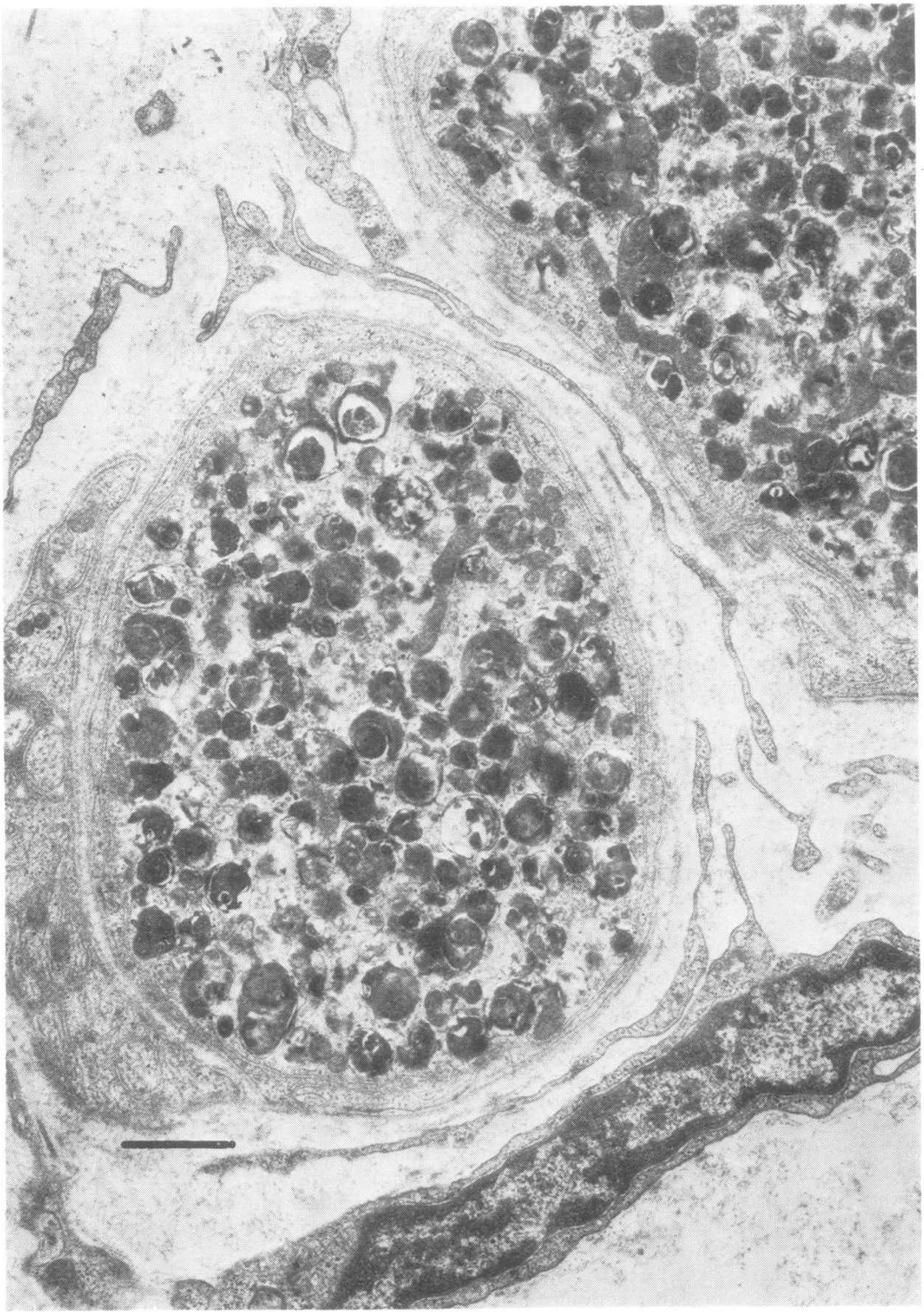

Fig. 5 Sandhoff disease. Amyelinic axons are distended by numerous dense pleomorphic inclusions (degenerattng or dystrophic axons). This feature is not specific to gangliosidoses but is, however, suggestive of it when especially pronounced (see also Dolman et al., 1977) (same techniques as Fig. 1. Scale $=1 \mu \mathrm{m}$ ). 


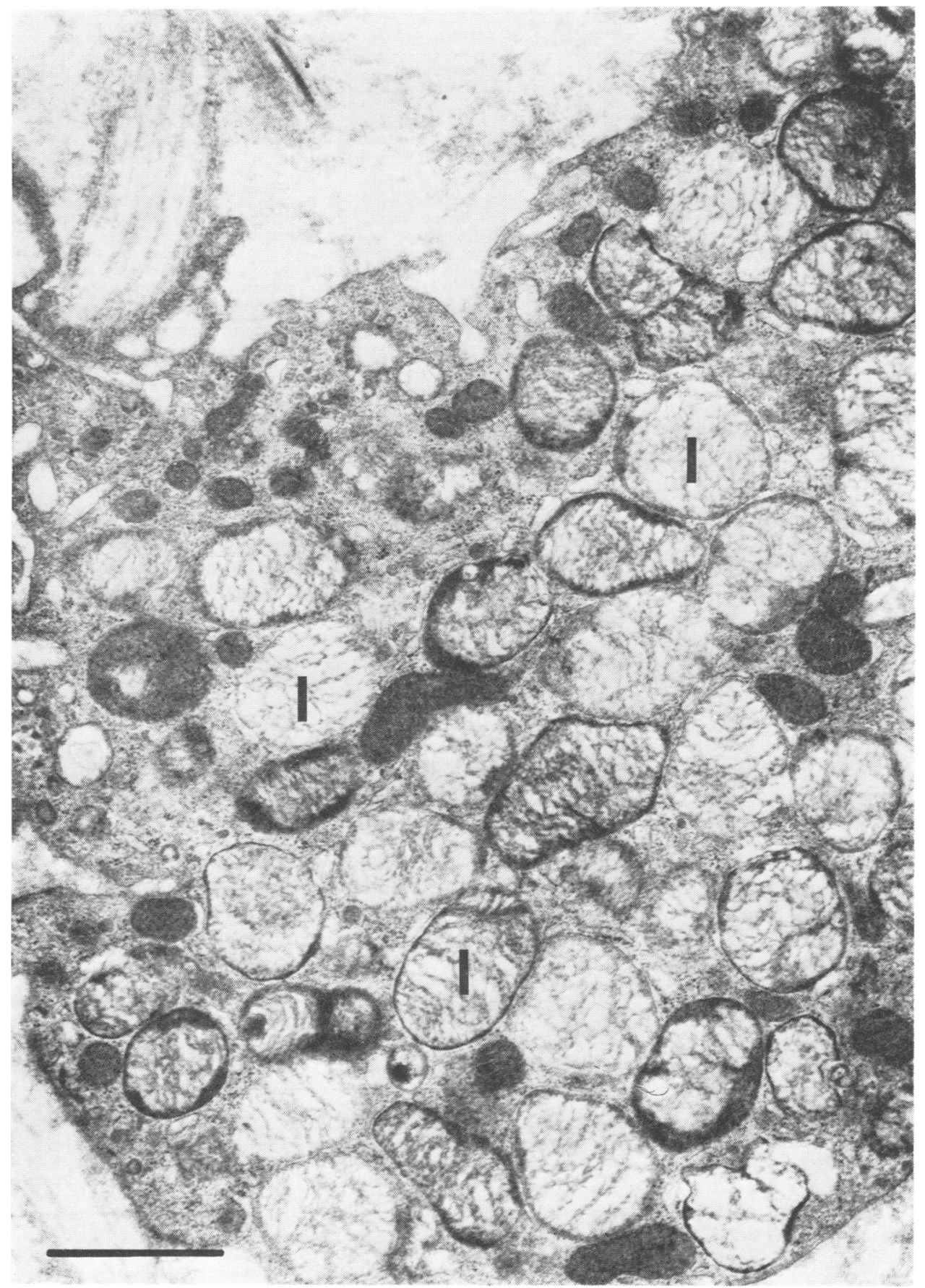

Fig. 6 Niemann-Pick disease (type A). A fibroblast is distended by partially washed out lamellar inclusions (I) (same techniques as Fig. 1. Scale $=1 \mu \mathrm{m}$ ). 
Table 6 Metabolic disorders to be further classified-morphological findings in skin

\begin{tabular}{ll}
\hline Diseases & Light $($ LM) and electron $(E M)$ microscopy \\
\hline Adrenoleucodystrophy & $\begin{array}{r}\text { LM: in one out of the four cases in which eccrine sweat glands could te examined, } \\
\text { a severe vacuolisation was found in the secretory coils. } \\
\text { EM : electron-lucent vacuoles containing a finely granular material, a few } \\
\text { microvacuoles and some lamellar debris in the eccrine sweat glands (one case). } \\
\text { Spicular, rectilinear, or slightly curved electron-lucent clefts in Schwann cells } \\
\text { around myelinic axons in three cases; minimal but qualitatively similar findings in } \\
\text { three other cases. }\end{array}$ \\
$\begin{array}{ll}\text { Encephalopathy with astrocytic lamellar inclusions } \\
\text { (Towfighi et al., 1975) }\end{array}$ & $\begin{array}{l}\text { LM: no abnormalities. } \\
\text { EM: first skin and peripheral nerve biopsies negative at age 4 y. } \\
\text { Brain biopsy at age 5 y showed astrocytic lamellar inclusions. } \\
\text { Skin, nerve, and conjunctival biopsies at age } 7 \text { y reveal free or membrane-bound } \\
\text { spicular clefts and elongated straight or slightly curved lamellar profiles } \\
\text { (reminiscent of the ones found in the astrocytic inclusions) in exoneurial } \\
\text { fibroblasts, Schwann cells, and endoneurial fibroblasts. }\end{array}$ \\
\hline
\end{tabular}

defined brain disorder with lamellar astrocytic residual bodies described by Towfighi et al. (1975). Since our first report (Martin et al., 1977a), we have performed new biopsies of skin, conjunctiva, and sural nerve. Lesions, not found in the first skin and nerve biopsies at ages 3 and 4 years, were now discovered in every examined tissue; they were most impressive in the sural nerve. Electron-lucent spicular clefts and elongated straight or slightly curved lamellar arrays were found in endo- and exoneurial fibroblasts and in Schwann cells, without any evidence of demyelination. Some of the inclusions were reminiscent of Krabbe's disease, but this diagnosis is ruled out by the normal levels, in cultured fibroblasts, of the enzyme galactose-ceramide- $\beta$ galactosidase, which is defective in Krabbe's disease. Adrenoleucodystrophy still remains a possibility since the location of the brain biopsy (at age 5 years) in the frontal lobe is not the best for diagnosing this condition. However, the clinical features of the patient's disease differ from those which are fairly specific for adrenoleucodystrophy and the exact nosological situation must await a postmortem study.

\section{ACID MALTASE DEFICIENCY}

In acid maltase deficiency, typical glycogen-filled vacuoles are found in nearly every cell type; they are more numerous and, therefore, easier to discover in younger patients. However, they were present in all cases, including adults, as already mentioned by Hug et al. (1973). Cultured fibroblasts from affected infants and children did contain similar vacuoles. In one adult, however, none were found as reported by Angelini et al. (1972) in three out of six cultures obtained from adult patients with acid maltase deficiency.

\section{Conclusions}

In most of the cases in Table 1 , positive diagnostic $\stackrel{+}{\rightleftharpoons}$ information was obtained by skin biopsy. The results of this morphological approach were especially valuable in the ceroid-lipofuscinoses for which we do not yet have reproducible and reliable enzymatic assays. In other disorders, the careful assessment of the distribution and of the ultrastructural features of the lesions, the presence of suggestive, if not specific, inclusions permitted an accurate diagnosis, or at least an adequate classifi-

Table 7 Acid maltase deficiency-morphological findings in skin

\begin{tabular}{ll}
\hline Clinical form & Electron microscopy \\
\hline Infantile & $\begin{array}{l}\text { Membrane-bound vacuoles filled with } \beta \text {-glycogen particles in all cell types including } \\
\text { eccrine sweat glands, smooth muscle cells, Schwann cells, fibroblasts etc. } \\
\text { Similar lesions in cultured fibroblasts: morphometric studies show that the glycogen- } \\
\text { filled vacuoles occupy } 1.8 \% \text { of the total cellular volume and } 81 \% \text { of the volume of } \\
\text { lysosomal vacuoles while the corresponding values approach } 0 \text { in three controls. } \\
\text { Similar lesions in all cell types and in cultured fibroblasts. } \\
\text { Morphometric studies show that the glycogen-filled vacuoles occupy } 3.6 \text { to } 4.6 \% \text { of }\end{array}$ \\
the total cellular volume and $61-81 \%$ of the volume of lysosomal vacuoles. \\
Quvenile & $\begin{array}{l}\text { Qualitatively similar lesions but the number of glycogen-filled vacuoles is markedly } \\
\text { decreased. In one case, cultured fibroblasts examined at the first passage did not } \\
\text { contain glycogen-filled vacuoles. }\end{array}$ \\
Similar but less numerous vacuoles in all cell types.
\end{tabular}


cation of the condition. This diagnosis should, of course, be confirmed by the appropriate enzymatic assays.

False positive information can only result from lack of adequate controls. If false negative reports cannot be avoided, their number can certainly be reduced by a thorough screening of semithin and thin sections.

A skin biopsy offers the possibility of studying many different cell types though not neurones. The absence of neurones, if we except the neurosensory endings occasionally discovered, represents, however, a minor drawback which is largely compensated for by the ubiquitous character of the storage phenomenon even in the absence of any clinically detectable skin alterations.

In association with chemical and enzymatic assays in the derived fibroblasts, it provides a simple but unique opportunity to combine morphology and biochemistry to diagnose storage disorders, eliminating the need for biopsies of brain, rectal wall, or vermiform appendix. Since the procedure is benign it can be repeated if necessary or offered to other affected members of the family or to siblings at risk.

In most of the cases in which uncultured skin of heterozygotes for the mutant genes causing the disorders listed in Table 1 has been studied, no morphological abnormalities were found. One probable exception will be Fabry's disease in which conjunctiva of female carriers shows definite abnormalities (Libert et al., 1976a).

It has not been our purpose to report systematically on cultured fibroblasts but the results have been much less informative than the direct study because of volatile morphological culturing artefacts.

We thank Drs H. Carton, P. Casaer, N. Chamoles, Th. and A. M. de Barsy, G. W. F. Edgar, J. P. Farriaux, K. Jacobs, M. C. Loonen, A. Lowenthal, J. P. Nuyts, J. G. W. Oonk, J. Radermecker, and $L$. van Bogaert who referred many patients to us. We want to thank especially J. G. Leroy, J. Libert, and L. Martin for their constant support, supply of information, and exchange of material. The skilful help of Miss L. De Wit and Mr R. Van Hove is also gratefully acknowledged.

\section{References}

Abe, K., Matsuda, I., Arashima. S., Mitsuyama, T., Oka, Y., and Ishikawa, M. (1976). Ultrastructural studies in fetal I-cell disease. Pediatric Research, 10, 669-676.

Angelini, C., Engel, A. G., and Titus, J. L. (1972). Adult acid maltase deficiency. Abnormalities in fibroblasts cultured from patients. New England Journal of Medicine, 287, 948-951.

Anzil, A. P., Blinzinger, K., Harzer, K., Reither, M., and Zimmermann, G. (1975). Cytosome morphology and distribution of generalized ceroid-lipofuscinosis in a twenty-eight month old boy with normal myeloperoxidase activity. Neuropädiatrie, 6, 259-283.

Arsénio-Nunes, M. L., and Goutières, F. (1975). An ultramicroscopic study of the skin in the diagnosis of the infantile and late infantile types of ceroidlipofuscinosis. Journal of Neurology, Neurosurgery, and Psychiatry, 38, 994-999.

Aula, P., Rapola, J., Autio, S., Raivio, K., and Karjalainen, O. (1975). Prenatal diagnosis and fetal pathology of I-cell disease (Mucolipidosis II). Journal of Pediatrics, 87, 221-226.

Belcher, R. W. (1972). Ultrastructure of the skin in the genetic mucopolysaccharidoses. Archives of Pathology, 94, 511-518.

Belcher, R. W. (1973). Ultrastructure and function of eccerine glands in the mucopolysaccharidozes. Archives of Pathology. 96, 339-341.

Bioulac, P., Mercier, M., Beylot, C., and Fontan, D. (1975). The diagnosis of mucopolysaccharidoses by electron microscopy of skin biopsies. Journal of Cutaneous Pathology. 2, 179-190.

Boniuk, V., Ghosh, M., and Galin, M. A. (1976). Conjunctival eye signs in $\mathrm{GM}_{1}$ type 1 gangliosidosis. Birth Defects: Original Article Series, The National Foundation, Vol. XII. No. 3, 543-551.

Carpenter, S., Karpati, G., and Andermann, F. (1972). Specific involvement of muscle, nerve, and skin in late infantile and juvenile amaurotic idiocy. Neurology (Minneapolis). 22, 170-186.

Carpenter, S., Karpati, G., Wolfe, L. S., and Andermann, F. (1973). A type of juvenile cerebromascular degeneration characterized by granular osmiophilic deposits. Journal of the Neurological Sciences, 18, 67-87.

Carpenter, S., Karpati, G., Andermann, F., Jacob, J. C.. and Andermann, E. (1977). The ultrastructural characteristics of the abnormal cytosomes in BattenKuf's disease. Brain, 100, 137-156.

Ceuterick, Ch., Martin, J. J., Casaer, P.. and Edgar, G. W. F. (1976). The diagnosis of infantile generalized ceroid-lipofuscinosis (type HagbergSantavuori) using skin biopsy. Neuropädiatrie, 7, 250-260.

de Baecque. C., Pollack, M. A., and Suzuki, K. (1976). Late infantile neuronal storage disease with curvilinear bodies. Systemic pathologic features. Archives of Pathology and Laboratory Medicine, 10, 139-144.

Dolman, C. L., and Chang, E. (1972). Visceral lesions in amaurotic familial idiocy with curvilinear bodies. Archives of Pathology, 94, 425-430.

Dolman, C. L., MacLeod, P. M., and Chang, E. (1975). Skin punch biopsies and leukocytes in a diagnosis of lipidoses. Canadian Journal of Neurological Sciences, 2, 67-73.

Dolman, C. L., MacLeod, P. M., and Chang, E. (1977). Fine structure of cutaneous nerves in ganglioside storage disease. Journal of Neurology, Neuro- 
surgery, and Psychiatry, 40, 588-594.

Farrell, D. F., and Sumi, S. M. (1977). Skin punch biopsy in the diagnosis of juvenile neuronal ceroidlipofuscinosis. A comparison with leukocyte peroxidase assay. Archives of Neurology (Chicago), 34, 39-44.

Hanai, J., Leroy, J., and O'Brien, J. S. (1971). Ultrastructure of cultured fibroblasts in I-cell disease. American Journal of Diseases of Children, 122, 3438.

Hashimoto, K., Gross, B. G., and Lever, W. F. (1965). Angiokeratoma corporis diffusum (Fabry). Histochemical and electron microscopic studies of the skin. Journal of Investigative Dermatology, 44, 119-128.

Hug, G., Schubert, W. K., and Soukup, S. W. (1973). Type II glycogenosis in adults. New England Journal of Medicine, 288, 216-217.

Kamensky, E., Philippart, M., Cancilla, P., and Frommes, S. P. (1973). Cultured skin fibroblasts in storage disorders. An analysis of ultrastructural features. American Journal of Pathology, 73, 59-80.

Kenyon, K. R. (1976). Ocular manifestations and pathology of systemic mucopolysaccharidoses. In Birth Defects: Original Article Series, The National Foundation, Vol. XII, No. 3, 133-153.

Kenyon. K. R., and Sensenbrenner, J. A. (1971). Mucolipidosis II (I-cell disease): Ultrastructural observations of conjunctiva and skin. Investigative Ophthalmology, 10, 555-567.

Kenyon, K. R., Quigley, H. A., Hussels, I. E., and Wyllie, R. G. (1972). The systemic mucopolysaccharidoses. Ultrastructural and histochemical studies of conjunctiva and skin. American Journal of Ophthalmology, 73, 811-833.

Koster, J. F., Niermeijer, M. F., Loonen, M. C. B., and Galjaard, H. (1976). Beta-galactosidase deficiency in an adult: A biochemical and somatic cell genetic study on a variant of $\mathrm{GM}_{1}$-gangliosidosis. Clinical Genetics, 9, 427-432.

Kousseff, B. G., Beratis, N. G., Strauss, L., Brill, P. W., Rosenfield, R. E.. Kaplan, B., and Hirschhorn, K. (1976). Fucosidosis type 2. Pediatrics, 57, 205-213.

Larbre, F., Chazalette, J. P., Guibaud, P., Richard, P., Pernoud, N., and Vanier, M. T. (1973). La gangliosidose à $\mathrm{GM}_{1}$ (forme infantile). A propos de cinq observations. Lyon Médical, 229, 335-346.

Lasser, A., Carter, M. D., and Mahoney, M. J. (1975). Ultrastructure of the skin in mucopolysaccharidoses. Studies performed before and after plasma infusion therapy. Archives of Pathology, 99, 173-176.

Leroy, J. G., and O'Brien, J. S. (1976). Mucolipidosis II and III: different residual activity of betagalactosidase in cultured fibroblasts. Clinical Genetics, 9, 533-539.

Libert, J. (1977). Diagnostic des maladies lysosomiales de stockage par biopsie conjonctivale. Manuscript awarded the Merck-Sharp-Dohme award for neurological sciences. Belgian Society of Neurology: Brussels.

Libert, J., and Danis, P. (1975). Diagnosis of type A
Niemann-Pick's disease by conjunctival biopsy. Pathologia Europaea, 10, 233-239.

Libert, J., and Tondeur, M. (1977). La mannosidose: Aspects anatomopathologiques en microscopie électronique. In Les Oligosaccharidoses. Edited by J. P. Farriaux. Editions Crouan et Roques: Lilles.

Libert, J., Tondeur, M., and Van Hoof, F. (1976a). The use of conjunctival biopsy and enzyme analysis in tears for the diagnosis of homozygotes and heterozygotes with Fabry disease. In Birth Defects: Original Article Series, The National Foundation, Vol. XII, No. 3, 221-239.

Libert, J., Van Hoof, F., and Tondeur, M. (1976b). Fucosidosis: ultrastructural study of conjunctiva and skin enzyme analysis of tears. Investigative Ophthalmology, 15, 626-639.

Libert, J., Tondeur, M., and Martin, J. J. (1977a). La fucosidose: Aspects anatomo-pathologiques en microscopie électronique. In Les oligosaccharidoses. Edited by J. P. Farriaux. Editions Crouan et Roques: Lilles.

Libert, J., Van Hoof, F., Farriaux, J. P., and Toussaint, D. (1977b). Ocular findings in I-cell disease (mucolipidosis type II). American Journal of Ophthalmology, 83, 617-628.

Libert, J., Martin, J. J., Evrard, P., Verougstraete, C., and Danis, P. (1978). Les céroide-lipofuscinoses: ultrastructure oculaire et diagnostic par biopsie conjonctivale. Archives Françaises d'Ophtalmologie (Paris). In press.

Loonen, M. C. B., van de Lugt, L., and Franke, C. L. (1974). Angiokeratoma corporis diffusum and lysosomal enzyme deficiency. Lancet, 2, 785.

Lyon, G., Hors-Cayla, M. C., Jonsson, V., and Maroteaux, P. (1973). Aspects ultrastructuraux et signification biochimique des granulations métachromatiques et autres inclusions dans les fibroblastes en culture provenant de lipidoses et de mucopolysaccharidoses. Journal of the Neurological Sciences, 19, 235-253.

MacLeod, P. M., Wood, S., Jan, J. E., Applegarth, D. A., and Dolman, C. L. (1977). Progressive cerebellar ataxia, spasticity, psychomotor retardation, and hexosaminidase deficiency in a 10-year-old child: Juvenile Sandhoff disease. Neurology (Minneapolis), 27, 571-573.

Martin, J. J., and Jacobs, K. (1973). Skin biopsy as a contribution to diagnosis in late infantile amaurotic idiocy with curvilinear bodies. European Neurology, 10, 281-291.

Martin, J. J., and de Groote, Ch. (1974). Involvement of the skin in late infantile and juvenile amaurotic idiocies (neuronal ceroid-lipofuscinoses). Pathologia Europaea, 9, 263-272.

Martin, J. J., and Libert, L. (1977). La mucolipidose II ou "I-cell disease". Aspects anatomopathologiques. In Les Oligosaccharidoses. Edited by J. P. Farriaux. Editions Crouan et Roques: Lilles.

Martin, J. J., Leroy, J. G., Farriaux, J. P., Fontaine, G., Desnick, R. J., and Cabello, A. (1975). I-cell disease (mucolipidosis II). A report on its pathology. Acta Neuropathologica (Berlin), 33, 285-305. 
Martin, J. J., Ceuterick, Ch., and Leroy, J. G. (1976a). Contribution de la biopsie cutanée au diagnostic des encéphalopathies métaboliques. Revue Neurologique (Paris), 132, 639-651.

Martin, J. J., Ceuterick, Ch., and Leroy, J. G. (1976b). Morphological study of skin biopsy specimens: Important contribution to the diagnosis of inherited neuro-degenerative disorders. Clinical Neurology and Neurosurgery, 79, 70-72.

Martin, J. J., Martin, L., and Ceuterick, Ch. (1977a). Encephalopathy associated with lamellar residual bodies in astrocytes (Towfighi, Grover and Gonatas 1975): A new observation. Neuropädiatrie, 8, 181189.

Martin, J. J., Ceuterick, Ch., Martin, L., and Libert, J. (1977b). Skin and conjunctival biopsies in adrenoleukodystrophy. Acta Neuropathologica (Berlin), 38, 247-250.

McLean, J., and Stewart, G. (1974). Fabry's disease: specific inclusions found on electron microscopy of fibroblast cultures. Journal of Medical Genetics, 11, 133-135.

Merin, S., Livni, N., Berman, E. R., and Yatziv, S. (1975). Mucolipidosis IV: ocular, systemic, and ultrastructural findings. Investigative Ophthalmology, 14, 437-448.

Neimann, N., Pernot, C., Marchal, Cl., and Fall, M. (1968). Insuffisance mitrale et maladie de Hurler. A propos de deux observations chez des demi-frères. Annales de Pédiatrie (Semaine des Hôpitaux de Paris), 44, 2380/P. 612-2386/P. 618.

O'Brien, J. S., Bernett, J., Veath, M. L., and Paa, D. (1975). Lysosomal storage disorders. Diagnosis by ultrastructural examination of skin biopsy specimens. Archives of Neurology (Chicago), 32, 592599.

O'Brien, J. S., Nyhan, W. L., Shear, C., Schmidt, L., and Veath, M. L. (1976a). Clinical and biochemical expression of a unique mucopolysaccharidosis. Clinical Genetics, 9, 399-411.

O'Brien, J. S., Gugler, E., Giedion, A., Wiessmann, U., Herschkowitz, N., Meier, C., and Leroy, J. (1976b). Spondyloepiphyseal dysplasia, corneal clouding, normal intelligence and acid betagalactosidase deficiency. Clinical Genetics, 9, 495504.

Oonk, J. G. W., van der Helm, H. J., and Martin, J. J. (1978). Low activity of hexosaminidase $A$ and B in two adult sisters with spinocerebellar degeneration. Neurology (Minneapolis). In press.

Patel, V., Watanabe, I., and Zeman, W. (1972). Deficiency of alpha-L-fucosidase. Science, 176, 426427.

Pilz, H., Goebel, H. H., and O'Brien, J. S. (1976). Isoelectric enzyme patterns of leukocyte peroxidase in normal controls and patients with neuronal ceroid-lipofuscinoses. Neuropädiatrie, 7, 261-270.

Quigley, H. A., and Goldberg, M. F. (1971). Conjunctival ultrastructure in mucolipidosis III (pseudoHurler polydystrophy). Investigative Ophthalmology, 10, 568-580.

Quigley, H. A., and Kenyon, K. R. (1974). Ultra- structural and histochemical studies of a newly recognized form of systemic mucopolysaccharidosis (Maroteaux-Lamy syndrome, mild phenotype). American Journal of Ophthalmology, 77, 809-818.

Rapin, I., Suzuki, K., Suzuki, K., and Valsamis, M. P. (1976). Adult (chronic) $\mathbf{G M}_{2}$ gangliosidosis. Atypical spinocerebellar degeneration in a Jewish sibship Archives of Neurology (Chicago), 33, 120-130.

Rapola, J., and Aula, P. (1977). Morphology of the placenta in fetal I-cell disease. Clinical Genetics, 11, 107-113.

Rapola, P., and Haltia, M. (1973). Cytoplasmic inclusions in the vermiform appendix and skeletal muscle in two types of so-called neuronal ceroidlipofuscinosis. Brain, 96, 833-840.

Rapola, J., Autio, S., Aula, P., and Nanto, V. (1974). Lymphocytic inclusions in I-cell disease. Journal of Pediatrics, 85, 88-90.

Roels, H., Quatacker, J., Kint, A., Vander Eecken, H., and Vrints, L. (1970). Generalized gangliosidosisGM $_{1}$ (Landing disease). II Morphological study. European Neurology, 3, 129-160.

Schaumburg, H. H., Powers, J. M., Raine, C. S., Suzuki, K., and Richardson, E. P. (1975). Adrenoleukodystrophy. A clinical and pathological study of 17 cases. Archives of Neurology (Chicago), 32, 577-591.

Scheie, H. G., Hambrick, G. W., and Barness, L. A. (1962). A newly recognized forme fruste of Hurler's disease (gargoylism). American Journal of Ophthalmology, 53, 753-769.

Spicer, S. S., Garvin, A. J., Wohltmann, H. J., and Simson, J. A. V. (1974). The ultrastructure of the skin in patients with mucopolysaccharidoses. Laboratory Investigation, 31, 488-502.

Spranger, J. W., and Wiedemann, H. R. (1970). The genetic mucolipidoses. Diagnosis and differential diagnosis. Humangenetik, 9, 113-139.

Tellez-Nagel, I., Rapin, I., Iwamoto, T., Johnson, A. B., Norton, W. T., and Nitowsky, H. (1976). Mucolipidosis IV. Clinical, ultrastructural, histochemical, and chemical studies of a case, including a brain biopsy. Archives of Neurology (Chicago), 33, 828-835.

Tenconi, R., Baccichetti, C., and Sartouri, E. (1972). Ultrastructure of metachromatic fibroblasts. American Journal of Diseases of Children, 124, 296-297.

Tommasi, M., Gylly, J., and Leung Tack Ki, A. (1971). La gangliosidose à $\mathrm{GM}_{1}$. Etude anatomoclinique de trois observations. Annales d'Anatomie Pathologique (Paris), 16, 133-152.

Tondeur, M., Vamos-Hurwitz, E., Mockel-Pohl, S. Dereume, J. P., Cremer, N., and Loeb, H. (1971). Clinical, biochemical, and ultrastructural studies in a case of chondrodystrophy presenting the I-cell phenotype in tissue culture. Journal of Pediatrics, 79, 366-378.

Towfighi, J., Grover, W., and Gonatas, N. K. (1975). Mental retardation, hypotonia, and generalized seizures associated with astrocytic "residual" bodies, An ultrastructural study. Human Pathology, 
6, 667-680.

van Haelst, U. J. G. M., and Gabreëls, F. J. M. (1972). The electron microscopic study of the appendix as early diagnostic means in BattenSpielmeyer-Vogt disease. Acta Neuropathologica (Berlin), 21, 169-175.

Van Hoof, F. (1972). Les mucopolysaccharidoses en tant que thésaurismoses lysosomiales. Thèse d'agrégation de l'enseignement supérieur de l'Université Catholique de Louvain. Vander: Louvain.

Vissian, L., Vaillaud, J. C., and Duplay, H. (1971). Mucopolysaccharidoses avec déficit en béta- galactosidase. Etude ultrastructurale de la peau. $\mathrm{La}$ Presse Médicale, 79, 2535-2538.

Vissian, L., Kermarec, J., Manassero. J., Duplay, H., and Vaillaud, J. C. (1970). Intérêt de la biopsie cutanée dans les sphingolipidoses et les mucopolysaccharidoses de l'enfant. A propos d'un cas de maladie de Norman-Landing avec recherches enzymatiques et ultra-structurales. Annales de Dermatologie et de Syphiligraphie (Paris), 97, 2138.

Wyatt, P. R., and Cox, D. M. (1977). Utilization of electron microscopy in the prenatal diagnosis of genetic disease. Human Heredity, 27, 22-37. 